\title{
Transgenic mice with targeted inactivation of the Col2a1 gene for collagen II develop a skeleton with membranous and periosteal bone but no endochondral bone
}

\author{
Shi-Wu Li, ${ }^{1}$ Darwin J. Prockop, ${ }^{1,4}$ Heikki Helminen, ${ }^{2}$ Reinhard Fässler, ${ }^{3}$ Tuomo Lapveteläinen, ${ }^{2}$ \\ Kari Kiraly, ${ }^{2}$ Alpo Peltarri, ${ }^{2}$ Jari Arokoski, ${ }^{2}$ Hui Lui, ${ }^{1}$ Machiko Arita, ${ }^{1}$ and Jaspal S. Khillan ${ }^{1}$ \\ ${ }^{1}$ Department of Biochemistry and Molecular Biology, Jefferson Institute of Molecular Medicine, Jefferson Medical College, \\ Thomas Jefferson University, Philadelphia, Pennsylvania 19107 USA; ${ }^{2}$ Department of Anatomy, University of Kuopio, \\ SF-70211 Kuopio, Finland; ${ }^{3}$ Department of Protein Chemistry, Max-Planck Institut für Biochemie, 82152 Martinsried bei \\ München, Munich, Germany
}

\begin{abstract}
Homologous recombination in embryonic stem cells was used to prepare transgenic mice with an inactivated Col2a1 gene for collagen II, the major protein component of the extracellular matrix of cartilage.

Heterozygous mice had a minimal phenotype. Homozygous mice developed into fetuses that were delivered vaginally but died either just before or shortly after birth. The cartilage in the mice consisted of highly disorganized chondrocytes with a complete lack of extracellular fibrils discernible by electron microscopy. There was no endochondrial bone or epiphyseal growth plate in long bones. However, many skeletal structures such as the cranium and ribs were normally developed and mineralized. The results demonstrate that a well-organized cartilage matrix is required as a primary tissue for development of some components of the vertebrate skeleton, but it is not essential for others.
\end{abstract}

[Key Words: Transgenic mice; Col2a1 gene; collagen II; cartilage matrix; vertabrate skeleton]

Received July 12, 1995; revised version accepted September 28, 1995.

The skeleton of vertebrates is one of the most complex structures in biology. A general assumption about the development of the skeleton is that cartilage is the primary tissue and that mineralized bone is a secondary tissue (see Hall 1975, 1992; Ham and Carmack 1979; Caplan 1988; Ross et al. 1989; Gilbert 1994; Reddi 1994). The observations that support the assumption are both phylogenic and ontogenic. The phylogenic observations are that early fishes such as sharks have a cartilaginous skeleton instead of a bony one. The ontogenic observations are that during embryonic development of most vertebrates, cartilaginous molds or models of limbs and vertebrae are first synthesized and then the models are mineralized (Ham and Carmack 1979; Caplan 1988; Ross et al. 1989; Hall 1992; Reddi 1994). In limbs, the initial cartilaginous models acquire a collar of mineralized bone, and the midshafts are invaded by blood vessels that erode the cartilage and transform it into marrow. The distal ends of the cartilage are retained so that the outer surfaces become the articular surfaces of joints. The inner surface of the cartilage at each of the distal ends becomes the epiphyseal growth plate in which the

${ }^{4}$ Corresponding author. cartilage continues both to proliferate and to be transformed into mineralized tissue as the bone grows longitudinally. Cartilage is not readily detectable as a precursor of the cranial bones, but the mesenchymal cells that become cranial bones have chondrogenic potential in that they differentiate into cartilage if deprived of calcium in vitro (Jacenko and Tuan 1986; Wong and Tuan 1995). Also, transient tracks of collagen II, the major component of the cartilage matrix, appear at epithelialmesenchymal interfaces early in the formation of the cranium as well as a number of other tissues, including otic vesicles, optic vesicles, the ventrolateral surfaces of the developing brain, the olfactory conchae, endocardial and the mesocardial tissues, the lateral and basal surfaces of the pharyngeal endoderm, and under the surfaces of ectoderm of the branchial arches /von der Mark and von der Mark 1977; Kravis and Upholt 1985; Thorogood et al. 1986; Cheah et al. 1991; Wood et al. 1991). Decades of observation and argumentation, however, have not resolved the question of whether cartilage is an active participant in the formation of the bony skeleton or whether it is simply an ontological precursor that is no longer essential for mineralization (see Hall 1975; Caplan 1988; Hall 1992; Gilbert 1994; Reddi 1994).

Cartilage is avascular and largely consists of widely 
dispersed chondrocytes embedded in a matrix of thin collagen fibers, proteoglycans, and water (Ham and Carmack 1979; Hall 1992; Gilbert 1994; Reddi 1994). The collagen fibers form intertwined arcades that are distended by the presence of proteoglycans and water, and thereby provide a resilient structure ideally suited to withstand compressive forces. Over six different types of collagen have been identified in cartilage (see Prockop and Kivirikko 1995), but collagen II accounts for $\sim 95 \%$ of the total collagen (Wu et al. 1987). It is $30 \%$ of the dry weight of developing cartilage and $\sim 60 \%$ of the dry weight of adult articular cartilage (Eyre et al. 1986; Wu et al. 1992). Therefore, it is reasonable to assume that collagen II is essential for the normal function of cartilage. The assumption is strengthened by the observations that mutations in the gene for collagen II (Col2a1) cause several kinds of chondrodysplasias (Horton 1992; Prockop et al. 1993; Ritvaniemi et al. 1995), a heterogeneous group of $>150$ heritable disorders that are characterized by malformation of cartilaginous structures and related defects such as cleft palate, deafness, mandibular hypoplasia, and disproportionate dwarfism (Rimoin and Lachman 1990; Horton 1992). Phenotypes similar to those seen in the patients with chondrodysplasias were produced in transgenic mice by expression of dominant-negative Col2a1 genes (Garofalo et al. 1991; Vandenberg et al. 1991; Metsäranta et al. 1992; Helminen et al. 1993).

Here we prepared transgenic mice in which the Col2a1 gene was inactivated by homologous recombination in embryonic stem cells. Heterozygous mice with one inactive allele had a mild phenotype with minimal changes in cartilaginous structures. Homozygous mice developed into fetuses that died either just before or shortly after delivery. Many body organs in the mice appeared to have developed normally, including mineralized structures such as cranial bones and ribs. However, there was no endochondrial bone or epiphyseal growth plate in long bones.

\section{Results}

\section{Preparation of transgenic mice}

A cosmid library containing genomic DNA from the inbred mouse strain FVB/N was screened with a 1.1-kb cDNA coding for the carboxy-terminal end of the mouse pro $\alpha 1(\mathrm{I})$ chain of type I procollagen. Apparently because of similarities in the nucleotide sequences (see Baldwin et al. 1989; S.-W. Li et al. 1995), the probe detected a clone containing a $30-\mathrm{kb}$ insert from the mouse Col2a1 gene. About $15 \mathrm{~kb}$ of the clone was sequenced. The clone was then used to prepare a construct of the mouse Col2a1 gene designed for homologous recombination in embryonic stem (ES) cells (Capecchi 1989; Mortensen 1993; Hasty et al. 1994). The construct extended from intron 31 to exon 43 of the Col2a1 gene (Fig. 1A). A neomycin-resistance gene was inserted into exon 35 , and the thymidine kinase gene from herpes simplex virus was ligated to the $5^{\prime}$ end of the construct (Mortensen 1993; Hasty et al. 1994). The neomycin-resistance gene

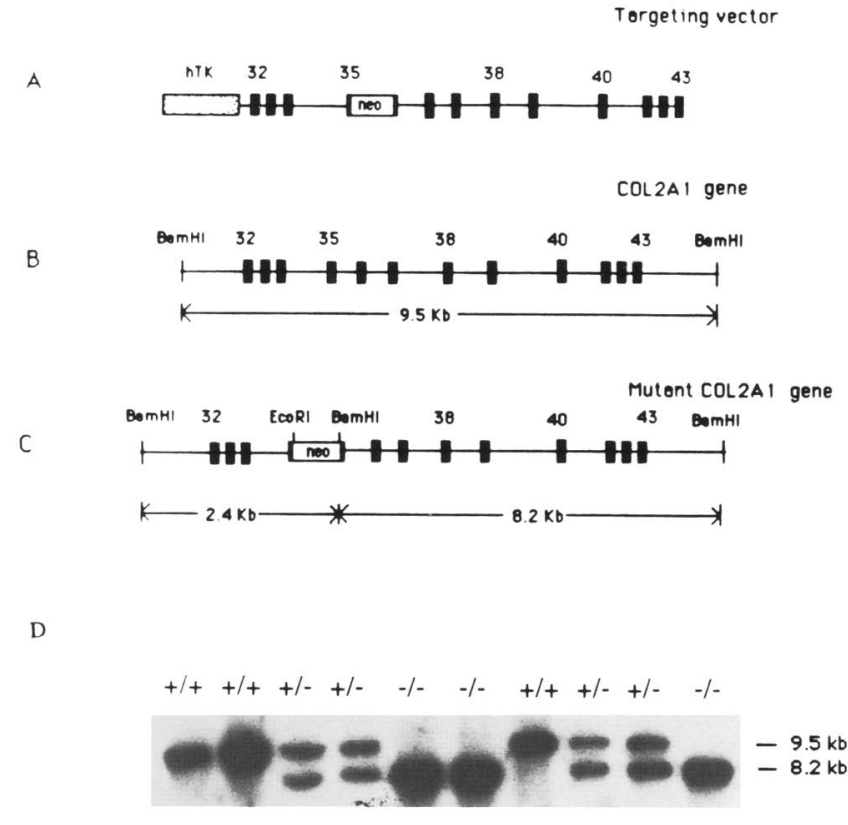

Figure 1. Gene constructs and assays for homologous recombination in ES cells. $(A)$ Gene construct employed; $(B)$ schematic of the target region of the endogenous COL2A1 gene; $(C)$ schematic of the target locus after homologous recombination; $|D|$ : Southern blot assay demonstrating the genotypes of offspring from matings of heterozygotes.

introduced an additional BamHI site into the targeted locus (Fig. 1C). Therefore, the cells were screened for the presence of a unique $8.2-\mathrm{kb}$ BamHI fragment. Of 320 clones of cells, 13 obtained after positive and negative selection were positive for the homologous recombination in one allele. The positive cells were used to prepare chimeric mice and then a line with germ-line transmission (Fig. 1D).

\section{Assays for expression of the Col2al gene in transgenic mice}

To ensure that the homologously replaced gene was not expressed as a functional protein, RT-PCR assays were carried out with RNA extracted from cartilage from homozygous and normal mice. Assays of homozygous mice showed RNA transcripts that terminated in the polyadenylation site of the neomycin-resistance gene in exon 35 (Fig. 2). There was no evidence in the homozygous mice of any longer transcripts. Because the amino acid sequences encoding the C-propeptide of the proal(II) chain are encoded by exons $49-52$ of the gene (Chu and Prockop 1993), and because the C-propeptide is essential to generate a functional proal(II) chain (Prockop 1990), the results indicated that the Col2a1 gene was not expressed as a functional proo 1 (II) chain.

The lack of expression of the Col2a1 gene in homozygous mice was confirmed by analysis of protein synthesized by cartilage cells isolated from the mice. As indicated in Figure 3, cultured cartilage cells from homozy- 


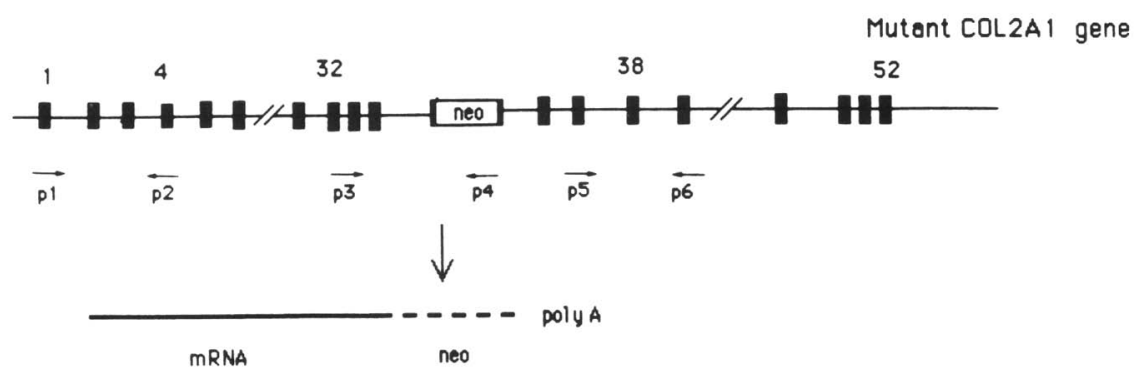

\section{RT-PCR}

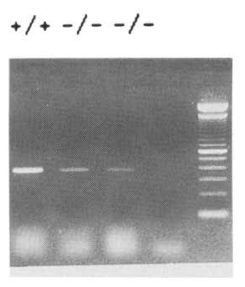

p1/p2

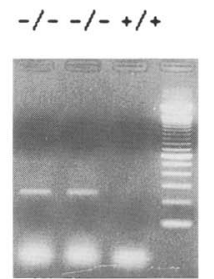

$03 / 04$

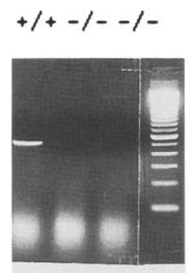

$05 / 06$ gous mice did not synthesize pro $\alpha$ (II) chains of collagen II. The levels synthesized by chondrocytes from heterozygous mice were about half normal (not shown). There was no evidence of a shortened proal(II) chain of $\sim 70$ $\mathrm{kD}$, the expected size if translation from the mutated allele terminated at the codon for amino acid 735 of the proal(II) chain, the site of insertion of the neomycinresistance gene (Fig. 1). Also, there was no evidence that the decreased expression of the Col2a1 gene was accompanied by a compensatory increase in synthesis of collagen XI, collagen IX, or other proteins by the chondrocytes (Fig. 3).

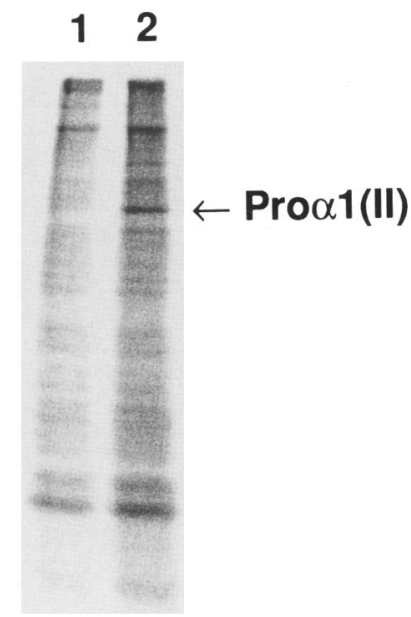

Figure 3. Synthesis of $\left[{ }^{14} \mathrm{C}\right]$ proline-labeled proteins by isolated chondrocytes. Cell lysates were analyzed by electrophoresis on a $7 \%$ polyacrylamide SDS gel and a phosphor storage imager. (Lane 1) Chondrocytes from a homozygous transgenic mouse; (lane 2) chondrocytes from a normal littermate.
Figure 2. RT-PCR assays for expression of the recombined Col2al gene in normal $(+/+)$ and homozygous $(-1-1$ mice. (Top) Schematic of the homologously recombined locus and location of PCR primers. (Bottom) Results of RT-PCR assays indicating that RNA transcripts in homozygous mice did not extend beyond the polyadenylation site in the neomycin-resistance gene.

\section{Phenotype of the transgenic mice.}

Heterozygous mice displayed a minimal phenotype with minor changes in the gross development of skeleton and soft tissues (Fig. 4). Of 120 newborn heterozygous mice, 5 had a cleft palate (Fig. 5) and, apparently as a result, were dead at birth or shortly thereafter. The remaining heterozygous mice were viable and readily bred. At birth, they were slightly smaller than normal littermates (Table 1), and they had slightly more bulged foreheads and shorter snouts (Fig. 4, top). Also, they had slightly shorter limbs (Table 1). The differences from control littermates were less apparent as the mice grew older. The skeletons of newborn heterozygous mice were normal in morphology and in the extent of mineralization structures such as the cranial bones, facial bones, the vertebrae, the ribs, and the long bones (Fig. 4, middle). Heterozygous embryos examined at 19 days or 15 days postcoitus also showed minimal differences from controls (Fig. 4, middle and bottom). The embryos were slightly smaller, but the morphology and mineralization of the skeleton was about the same as controls. Similar minimal differences from controls were seen when stained skeletons were examined from embryos that were 13 and 18 days postcoitus (not shown).

Homozygous mice were delivered vaginally but were dead as soon as they were examined (Fig. 4, top). All lacked a palate with no evidence of palatal shelves (Fig. 5). It was not possible to establish whether they had died in utero, just prior to delivery, or just after birth because they were unable to breathe. The newborn mice were $\sim 25 \%$ smaller than normal littermates. They had a bulged forehead, a short snout, and greatly shortened limbs. In newborn homozygous mice, the skull was small but the cranial bones were well formed and apparently normally mineralized. The facial bones were truncated. The clavicles were normal. The ribs were short- 

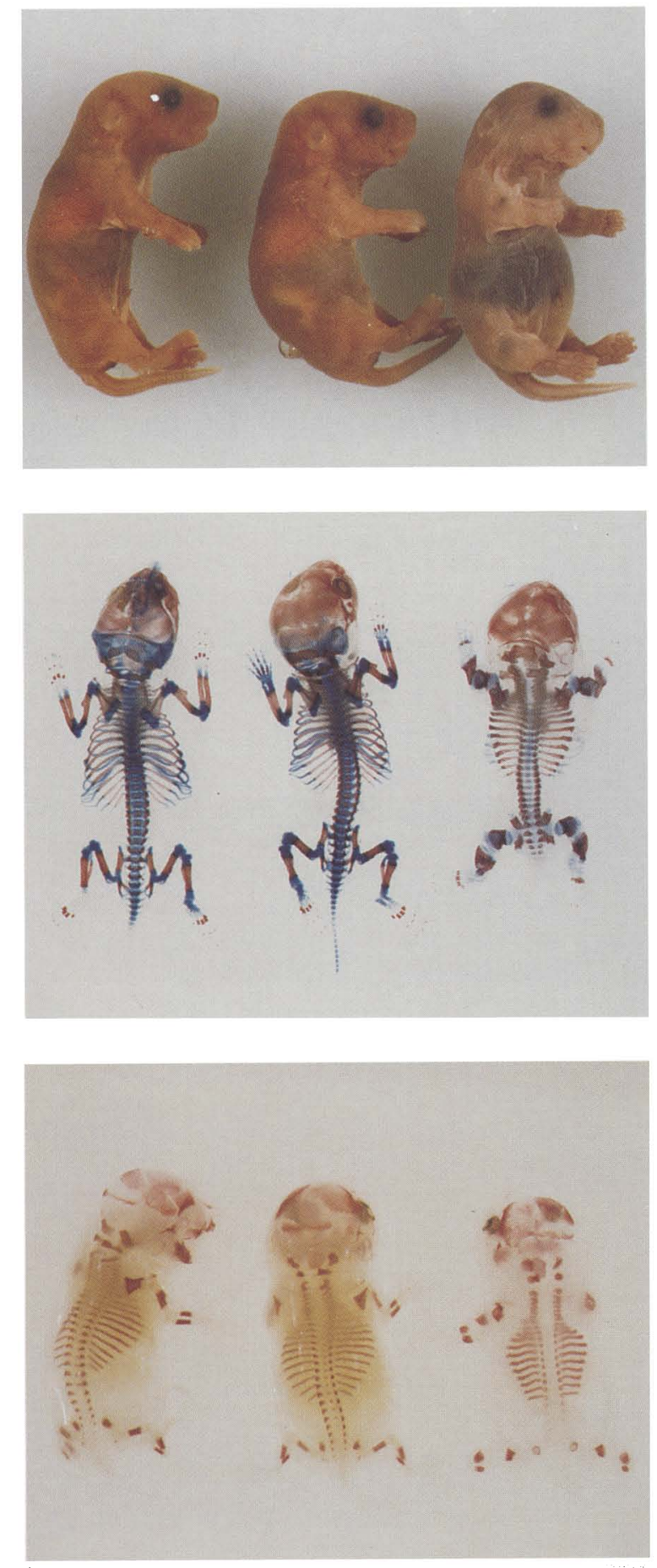

Figure 4. Normal, heterozygous, and homozygous mice (left to right). (Top) Photographs of newborn mice; (middle) stained skeletons of embryos removed at 19 days of gestation; (bottom) stained skeletons of embryos removed at 15 days of gestation.

ened but well mineralized. When seen end-on, the unmineralized centers of the ribs appeared larger than in controls (not shown). The thorax was small, and the sternum was not mineralized. The vertebral bodies and

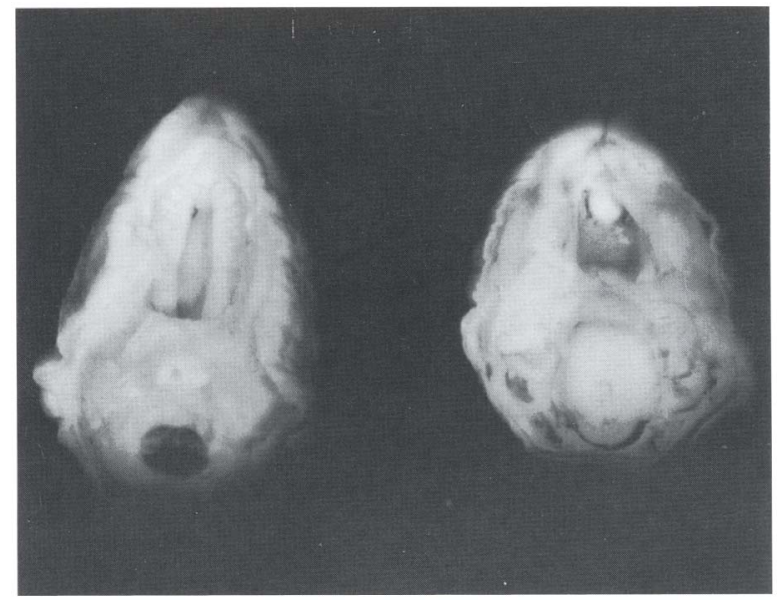

Figure 5. Photographs of cleft palates in heterozygous (left) and homozygous (right) newborn mice. No palatal shelf is seen in the homozygous mouse.

arches appeared well mineralized, but the dorsal laminae were not mineralized. There was a decrease in the number of mineralized vertebrae in the tail (Fig. 4, middle). The shortened long bones had thickened collars of cortical bone and greatly increased diameters. When seen end-on, they appeared to have enlarged bone cavities and extremely thick cortical bone (not shown). The hands and feet were small with short bones. There was decreased ossification of the middle phalanges and none of the distal phalanges.

In homozygous embryos examined at 19 or 15 days postcoitus, most of the same differences from controls were seen (Fig. 4, bottom): The embryos were smaller and the limbs were greatly shortened; the skull was small but normally mineralized; the ribs were shortened but normally mineralized; the vertebrae were less mineralized than in control or heterozygous embryos; and the shortened long bones had enlarged marrow cavities when seen end-on. Similar differences from controls were seen in embryos examined at 13 and 18 days postcoitus (not shown).

\section{Ultrastructure of tissues}

Light microscopy of histologic sections of newborn mice

Table 1. Body weights and lengths of long bones from 2-week-old wild-type and heterozygous mice

\begin{tabular}{lccc}
\hline & $\begin{array}{c}\text { Body } \\
\text { weight } \\
\text { (grams })\end{array}$ & femur & tibia \\
\cline { 3 - 4 } & & & Length $\langle\mathrm{mm}|$ \\
\hline $\begin{array}{c}\text { Normal } \\
(n=6)\end{array}$ & $6.98 \pm 0.15^{\mathrm{a}}$ & $6.52 \pm 0.26$ & $9.85 \pm 0.19$ \\
$\begin{array}{c}\text { Heterozygous } \\
(n=5)\end{array}$ & $6.05 \pm 0.65^{\mathrm{a}}$ & $5.68 \pm 0.43^{\mathrm{a}}$ & $8.22 \pm 0.26^{\mathrm{a}}$
\end{tabular}

Data expressed as mean \pm S.D.

${ }^{a} P<0.01$ significant difference between wild-type and heterozygous mice (Student's $t$-test). 
indicated that many structures appeared normal in both heterozygotes and homozygotes. The vertebral arches of homozygous mice were rudimentary and unclosed (Fig. $6 \mathrm{C})$. In the kidneys, there was evidence of hyperemia and interstitial hemorrhage, but otherwise the organ appeared normal (Fig. 6F). The alveoli of the lungs were closed (Fig. 6I), apparently because the animals were unable to breathe. There were no apparent abnormalities of the eye (Fig. 7C), liver (Fig. 7F), and thymus (Fig. 7I). Heart valves of the heart were shorter (Fig. 8B) but otherwise well formed.

The most obvious changes were in cartilaginous tissues. In heterozygous 15-day-old embryos, there was slight disorganization of the normal columnar array of chondrocytes near the growth plate of the knee (Fig. 9B). Also, there was a reduced birefringence caused by the collagen network (Fig. 9E). In homozygous 15-day-old embryos, there was almost complete disorganization of the growth plate (Fig. 9C) and loss of birefringence (Fig. 9F). The articular surfaces of the knee were highly irregular. There were no distinct zones of proliferative and hypertrophic chondrocytes. Also, there was no distinct growth plate and no mineralization of the growth plate. Instead, there was only an incomplete network of woven bone. Examination of nasal septum showed a similar disorganization of the cartilage and loss of birefringence (not shown). Although the diaphyses of long bones contained cavities, no marrow was seen.

Electron microscopy of cartilage showed a slight decrease of fibrillar structures in the matrix of heterozygous mice and complete lack of discernible fibrils in homozygous mice (Fig. 10). Chondrocytes from homozygous mice were often distended and showed signs of degeneration.

\section{Discussion}

The role of collagen II and cartilage in embryonic development

The transgenic mice produced here totally lacked collagen II. Because collagen II accounts for $30 \%-60 \%$ of the

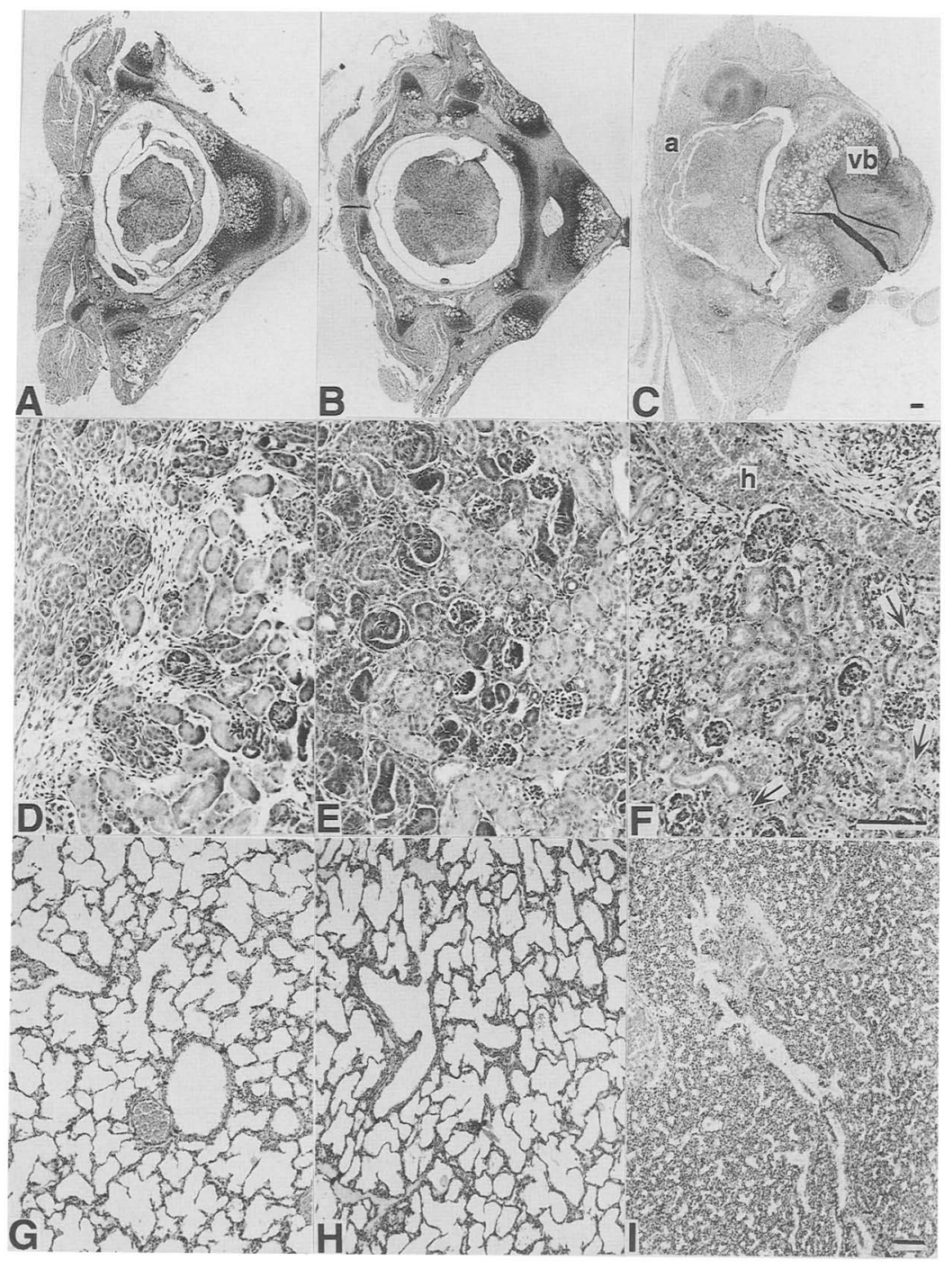

Figure 6. Micrographs of spine, kidney, and lung tissues of newborn mice. (Top) Transverse sections through of spine of normal $|A|$, heterozygous $(B)$, and homozygo $(C)$ mice. In the homozygote, the vertebral arch (a) is rudimentary and unclosed. There are no apparent changes in the vertebral body (vb). (Middle) Sections through kidney of normal $\langle D|$, heterozygous $(E)$, and homozygous $(F)$ mice. In the homozygote, there are signs of hyperemia (h), and hemorrhage (arrows). (Bottom) Sections through lung of normal $(G)$, heterozygous $(H)$, and homozygous $(I \mid$ mice. In the homozygote, the alveoli are closed. Hematoxylin-eosin staining. Bar for each row, $100 \mu$. 
Li et al.

Figure 7. Micrographs of eye, liver, and thymus of newborn mice. (Top) Sections through eye of normal $(A)$, heterozygote $(B)$, and homozygous (C) mice. (Middle) Sections through liver in same mice. (Bottom) Sections through thymus in the same mice.

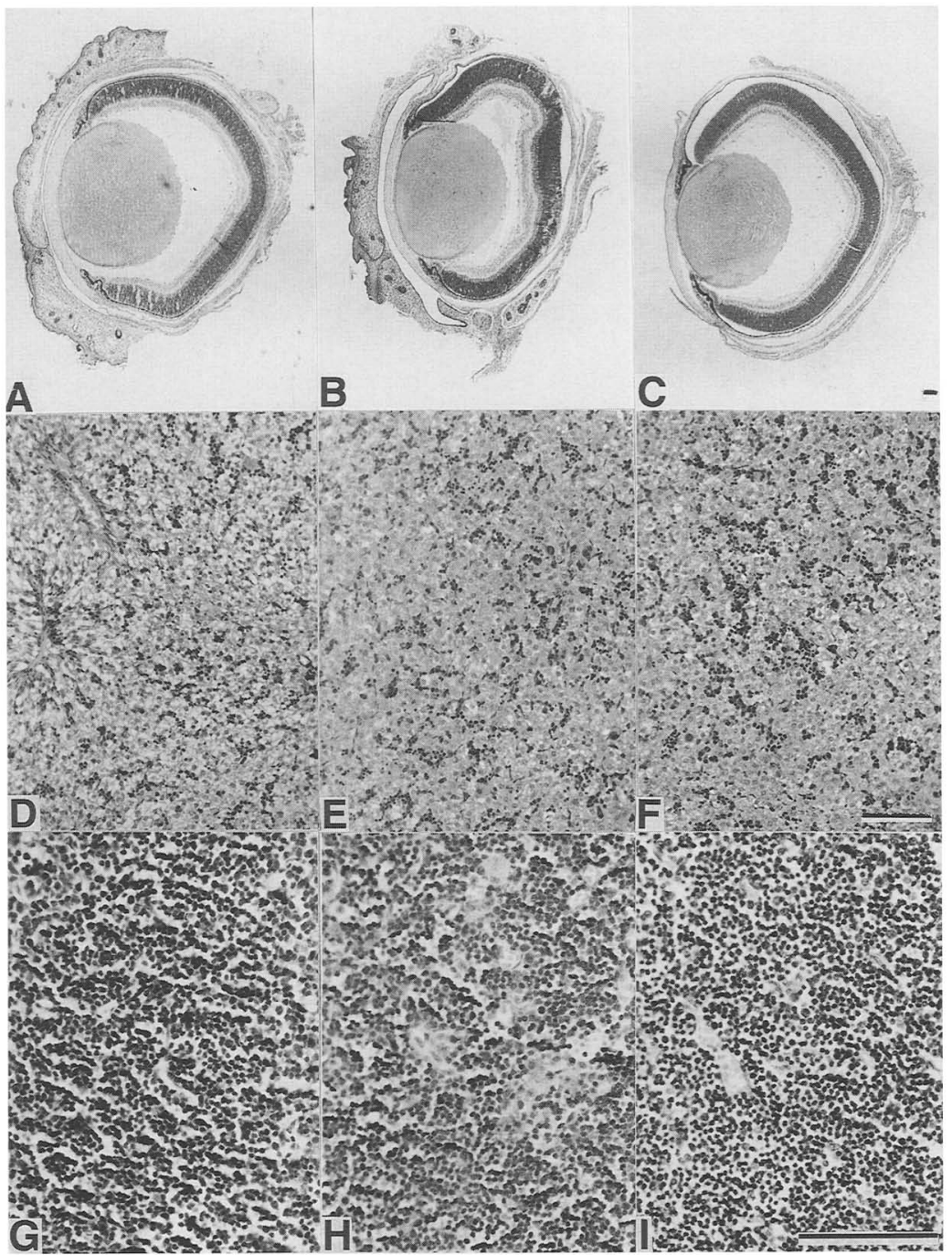

dry weight of the cartilage matrix (Eyre et al. 1986; Wu et al. 1987, 1992), the mice provided a test for several longstanding hypotheses about the role of both collagen II and a well-organized cartilage matrix in development.

One hypothesis about collagen II is that the pattern of secretion of the protein in early embryonic development constitutes a morphogenic signal that specifies the form

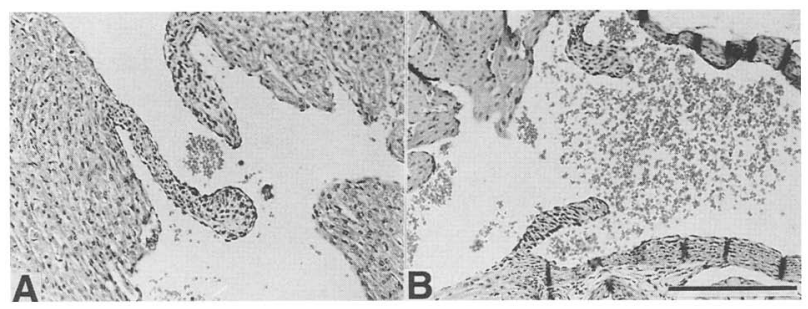

Figure 8. Heart valves of newborn heterozygous $(A)$, and homozygous $(B)$ mice. In the homozygotes valves appear shorter. Hematoxylin-eosin staining. $\operatorname{Bar}(A, B) 100 \mu \mathrm{m}$. of most of the endoskeleton of vertebrates (Ham and Carmack 1979; Thorogood et al. 1986; Thorogood 1988; Ross et al. 1989; Cheah et al. 1991; Wood et al. 1991; Hall 1992; Reddi 1994). The results here do not support this hypothesis, as they demonstrate that synthesis of collagen II is not essential for the morphogenesis of a number of tissues and organs.

Another long-standing hypothesis about the development of vertebrates is that assembly of a cartilage model is an essential preliminary step for the formation of long bones (see Ham and Carmack 1979; Ross et al. 1989; Gilbert 1994; Hall 1992; Reddi 1994). The hypothesis is based on the observation that the cartilage models form first and then are gradually replaced by bone. It is also based on the observation that the cartilage is frequently synthesized early in the repair of most fractures of bone. The observations in the homozygous mice prepared here demonstrate that a well-organized cartilage is not an essential for the initial mineralization of long bones or the synthesis of periosteal bone. Also, it is not essential for formation of the cavities of long bones. However, a well- 

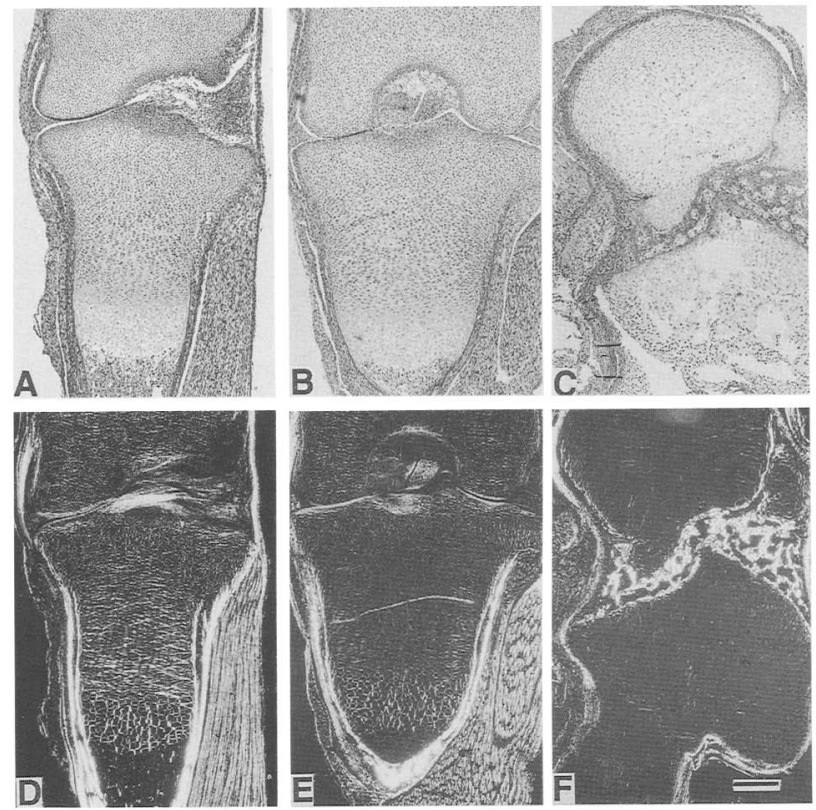

Figure 9. Light $(A-C)$ and polarized light microscopy $(D-F)$ of knee cartilages of 15-day-old embryos. $(A, D)$ Femoral and tibial epiphyseal cartilages from normal embryos. $(B, E)$ Femoral and tibial epiphyseal cartilages from heterozygous embryos. There was a slight disorganization of the growth plate chondrocyte columns $(B)$, and reduced birefringence of the matrix $(E) .(C, F)$ Femoral and epiphyseal cartilages from homozygous mice. Cartilage-like tissue was present only peripherally in the bone primordium $(C)$. There was weak birefringence reflecting from cell borders, not from matrix $(F)$. The membranous (periosteal) bone shows strong birefringence in both control $(D)$ and transgenic embryos $\langle E, F\rangle$. Picrosirius staining. Bar $(A-F), 200 \mu \mathrm{m}$.

formed cartilage model is apparently important for capillary invasion of the bone cavities to form marrow (see Caplan 1988). The reasons for the abnormally thick periosteal bone in the homozygous mice are not apparent. It may be either a consequence of the inability of the bone to grow longitudinally or a compensatory thickening as a result of mechanical stimuli on a bone that lacks internal cartilage.

Another and related hypothesis about development of the endoskeleton is that the presence of cartilage and well-organized hypertrophic chondrocytes is essential for formation and growth of the epiphyseal growth plate of long bones (Ham and Carmack 1979; Ross et al. 1989; Gilbert 1994; Hall 1992; Reddi 1994). The results here provide the first direct evidence for this hypothesis, as the marked disorganization produced by the lack of collagen II prevented the formation of an epiphyseal growth plate. In contrast, mineralization of cranial vault bones appeared normal. Therefore, the results support previous assumptions that cranial bones are a distinct form of membranous bones that do not require prior synthesis of either collagen II or a well-formed cartilage matrix.

The observations about mineralization of the vertebrae present a more complex picture. The vertebral bodies were mineralized, but more slowly than in controls. Also, the dorsal laminae were not mineralized. Therefore, the results suggest that neither type II collagen nor a well-formed cartilage matrix is essential for the condensation of sclerotome cells to form the ventral regions of the vertebral bodies but they are essential for the dorsal structures. Accordingly, the role of collagen II and the need for a well-formed cartilage matrix in the development of the structures may be related to specific interactions between matrix proteins and regulatory proteins such as the protein products of the Pax gene family (see Tremblay and Gruss 1994) or Sonic hedgehog (Johnson and Tabin 1995).

\section{Comparison of the phenotype to other chondrodysplasias}

Chondrodysplasias and related phenotypes in man and mice have been shown to be caused by mutations in a series of collagen genes that include Col2a1 (Horton 1992; Prockop et al. 1993; Ritvaniemi et al. 1995), Col9a1 (Nakata et al. 1993; Fassler et al. 1994), Col10a1 (Warman et al. 1993; McIntosh et al. 1995), Col11a1 (Y.

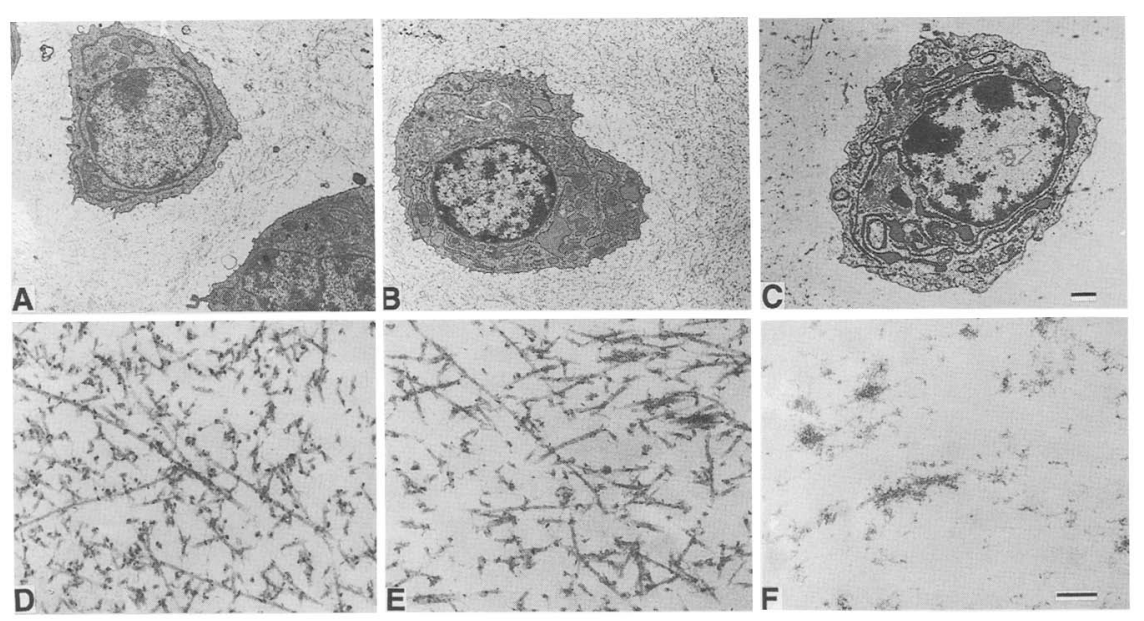

Figure 10. Electron microscopy of cells and matrix from cartilage of the distal part of femur from newborn mice. $(A, D)$ Cells and matrix from controls; $\langle B, E)$ cells and matrix from heterozygous transgenic mouse; $(C, F)$ cells and matrix from homozygous transgenic mouse. Cells are typically dilated $(C)$, and the matrix is devoid of collagen fibrils. Bar $(A-C) 1 \mu \mathrm{m} ;(D-E)$, $200 \mathrm{~nm}$. 
Li et al. 1995), and Col11a2 (Y. Li et al. 1995; Vikkula et al. 1995). Also, a chondrodysplasia in mice is caused by a mutation in the gene for the large proteoglycan aggregan (Watanabe et al. 1994). A human chondrodysplasia defined as achondroplasia is caused by mutations in the gene for fibroblast growth factor receptor 3 (Shiang et al. 1994) and a metaphyseal chondrodysplasia by mutations in a gene for parathyroid hormone-related peptide receptor (Schipani et al. 1995). In the case of the Col2a1 gene, a recent survey (Ritvaniemi et al. 1995) indicated that mutations in the gene are found in $>20 \%$ of patients with severe or moderately severe cartilage disorders such as lethal hypochondrogenesis, the Wagner-Stickler syndrome, and spondyloepiphyseal dysplasia. In addition, mutations in the gene are found in as many as $2 \%$ of the patients with early onset familial osteoarthritis with evidence of a mild chondrodysplasia. Most of the mutations in the Col2a1 gene appear to be dominant-negative mutations similar to the dominant-negative mutations seen in most probands with mutations in other collagen genes (see Kuivaniemi et al. 1991; Prockop et al. 1993; Ritvaniemi et al. 1995). However, the first four mutations found in patients with the Stickler syndrome were single base mutations that introduced premature termination codons for translation. These four mutations causing the Stickler syndrome were also the first premature termination codons detected among $>200$ mutations in the genes for the major fibrillar collagens (Col1a1, Col1a2, Col2a1, and Col3a1). The results suggested, therefore, that decreased expression of the Col2a1 gene had some special causal relationship to the phenotype of the Stickler syndrome that is characterized by vitreous degeneration leading to retinal detachment and is frequently associated with hypofacies, cleft palate, and variable dystrophic changes in cartilage. The heterozygous mice prepared here might well, therefore, be appropriate models for the Stickler syndrome. The eyes of mice, however, are different from human eyes in that most of the vitreous is replaced by a thick lens (Pugh 1968). Therefore, they cannot be used to follow degeneration of gel-like vitreous that secondarily produces retinal detachment in patients with the Stickler syndrome. The homozygous mice, in contrast, had a more severe phenotype than is seen with the Stickler syndrome. Instead, they most closely resembled the Langer-Saldino variant of achondrogenesis in which cartilage from one proband was shown previously to lack collagen II but in which the genetic defect was not defined (Eyre et al. 1986).

\section{Materials and methods}

\section{Gene construct}

The targeting vector contained a 4.7-kb BamHI-Xhal fragment that extended from exon 32 to 43 , the neomycin-resistant gene (PMCl-neo, Stratagene) inserted into the Xhol site located in exon 35 , and the herpes simplex virus thymidine kinase gene (pHSV-106, GIBCO BRL) inserted into a BamHI site at the 5' end (Fig. 1). The plasmid was linearized with NotI and electroporated into ES cells from $129 / \mathrm{Sv}$ mice with $35 \mu \mathrm{g} / \mathrm{ml}$ of DNA and $10^{7}$ cells $/ \mathrm{ml}$ at $830 \mathrm{v}$ and $3.0 \mu \mathrm{F}$. The cells were plated onto a feeder layer of mouse fibroblasts that had been transfected with a neomycin-resistance gene and selected for resistance of G418. The cells on the feeder layer were selected for 7-10 days with $400 \mu \mathrm{g} / \mathrm{ml}$ of G418 and $10 \mu \mathrm{M}$ of Gancyclovir (SYNTEX Inc.). Resistant clones were expanded for Southern blot analysis. One of 13 correctly targeted ES clones was injected into 2.5day-old blastocysts removed from pregnant mice of the C57BL/6 line. The blastocysts were inserted in the uterine horns of pseudopregnant mice of the CD-1 line. Mice that were chimeric by coat color were bred to wild-type mice from the C57BL/6 strain. Transgenic offspring were identified by Southern blot analysis for germ-line transmission of the mutated allele.

\section{Southern blot analyses}

DNA extracted from tail was digested with proteinase $\mathrm{K}$, phenol extraction, and isopropanol precipitated. The DNA was digested with BamHI, separated on agarose gel, and transferred to a nylon membrane (Biotrans; ICN). The membrane was probed with a 4.8-kb XbaI-BamHI fragment that spanned exons 44-52 of the mouse Col2a1 gene and that was labeled with $\left[{ }^{32} \mathrm{P}\right] \mathrm{dCTP}$ by random primer extension.

\section{$R T-P C R$ assays}

RNA was extracted from limbs of mice with guanidinium isothiocianate. RT-PCR was carried out with a commercial kit (First-Strand cDNA synthesis, Pharmacia) and random primers, and then with the following specific primers: p1, TCGCGGTGAGCCATGATCCGC; p2, GAGGGCCAGGAGGTCCTCTGG; p3, TGGTCCCAAAGGTGCATCTGG; p4, GAAACATTCCAGGCCTGGGTG; p5, GGTGCTGATGGCAGCCTGG; and p6, AGCACCAGTCTCACCACGATCAC. The products were separated by electrophoresis on a $2.5 \%$ agarose gel. Each PCR product was sequenced by cycle sequencing with fluorescently labeled dNTPs on an automated instrument (ABI).

\section{Protein synthesis by isolated chondrocytes}

Sternae were dissected from mice, stripped of perichondrium, washed in Hank's solution, and then digested for $30 \mathrm{~min}$ at $37^{\circ} \mathrm{C}$ with $0.25 \%$ trypsin and $0.1 \%$ crude collagenase (Type I; Sigma) in $\mathrm{Mg}^{2+}$ and $\mathrm{Ca}^{2+}$-free phosphate buffered saline. Samples were centrifuged, and the sediment was discarded to eliminate contaminating periochondrial fibroblasts. The sternal cartilages were then cut into small pieces and digested with the same enzyme solution for $90 \mathrm{~min}$ at $37^{\circ} \mathrm{C}$. The released chondrocytes were washed twice with Ham's F12 medium plus $10 \%$ fetal calf serum and plated onto 96-well microtiter plates at a cell density of $10^{4} / \mathrm{cm}^{2}$. Cells were grown in Ham's F12 medium containing $10 \%$ fetal calf serum, penicillin $(50 \mathrm{U} / \mathrm{ml})$, and streptomycin $(50$ $\mu \mathrm{g} / \mathrm{ml})$ at $37^{\circ} \mathrm{C}$ in $5 \% \mathrm{CO}_{2}$ in air overnight. To radiolabel cell proteins, the medium was replaced with fresh medium containing $5 \mu \mathrm{Ci} / \mathrm{ml}$ of $\left[{ }^{14} \mathrm{C} \mid\right.$ proline, $50 \mu \mathrm{g} / \mathrm{ml}$ of ascorbic acid, and 2.5 $\mathrm{mM} \beta$-aminopropionitrile. After incubation for $24 \mathrm{hr}$, the medium was removed by centrifugation and the cell pellets washed with fresh medium. The cells were lysed by homogenization in $0.5 \mathrm{ml}$ of buffer that contained $50 \mathrm{~mm}$ Tris- $\mathrm{HCl}$ (pH 6.8), $2 \%$ SDS, $6 \mathrm{M}$ urea, $0.015 \%$ bromophenol blue, $5 \%$ 2-mercaptoethanol, $25 \mathrm{~mm}$ EDTA, $10 \mathrm{~mm}$ ethylmaleimid, $1 \mathrm{mM}$ phenylmethanesulfonyl fluoride, and $0.01 \% \mathrm{NaN}_{3}$. The homogenate was shaken at $4^{\circ} \mathrm{C}$ for $2 \mathrm{hr}$, heated at $100^{\circ} \mathrm{C}$ for $5 \mathrm{~min}$, and centrifuged for $5 \mathrm{~min}$ at $12,000 \mathrm{~g}$. The medium was precipitated overnight by adding one-fourth volume of $25 \%$ PEG (m.w. 8000 ) in $0.5 \mathrm{M}$ Tris- $\mathrm{HCl}$ buffer $(\mathrm{pH} 7.4), 2.0 \mathrm{M} \mathrm{NaCl}$, and $0.05 \% \mathrm{NaN}_{3}$. The precipitates were dissolved in $30 \mu \mathrm{l}$ of $0.1 \mathrm{M}$ Tris- $\mathrm{HCl}$ buffer 
(pH 7.4), $0.4 \mathrm{M} \mathrm{NaCl}$, and $0.01 \% \mathrm{NaN}_{3}$ and mixed with onefourth volume of $5 \times$ electrophoresis buffer $(1 \times$ was $2 \%$ SDS, $2 \%$ glycerol, $0.1 \%$ bromophenol blue, $1 \% 2$-mercaptoethanol in $150 \mathrm{~mm}$ Tris- $\mathrm{HCl}$ buffer at $\mathrm{pH} 6.8$ ). The samples from cells and medium were heated for $5 \mathrm{~min}$ at $94^{\circ} \mathrm{C}$, and separated by electrophoresis in SDS on a 7\% polyacrylamide gel. The gel was dried and analyzed with a phosphor storage imager (PhosphorImager, Molecular Dynamics).

\section{Light and electron microscopy}

Tissues of anesthetized newborn and adult mice were fixed by perfusion through the heart with $2 \%$ paraformaldehyde and $2.5 \%$ glutaraldehyde buffered to $\mathrm{pH} 7.3$ with $0.1 \mathrm{M}$ phosphate buffer. After 10-15 min of perfusion, nasal cartilage and knee joints were immersed overnight in the same fixative at $4^{\circ} \mathrm{C}$. Decalcification was carried out by immersing the tissues in $10 \%$ EDTA and $0.5 \%$ paraformaldehyde buffered with $0.1 \mathrm{M}$ phosphate buffer (pH 7.4). The solution was changed every other day for 14 days. Samples for electron microscopy were postfixed with $1 \%$ osmium tetroxide in $0.1 \mathrm{M}$ cacodylate buffer $(\mathrm{pH} 7.4)$ for $2 \mathrm{hr}$ at $20^{\circ} \mathrm{C}$, washed three times with the cacodylate buffer, and then placed in $1 \%$ tannic acid in $0.1 \mathrm{M}$ cacodylate buffer $(\mathrm{pH}$ 7.4) for $30 \mathrm{~min}$ to $1 \mathrm{hr}$. After buffer washings and dehydration in ascending series of ethanol solutions, the specimens were embedded in epon. Sections $50-60 \mathrm{~nm}$ thick were cut and stained with uranyl acetate for $30 \mathrm{~min}$, followed by staining with lead citrate for 2-4 min. They were examined with a JEM $1200 \mathrm{EX}$ electron microscope (JEOL, Tokyo, Japan).

For polarized light microscopy, $5-\mu \mathrm{m}$-thick sections were cut from paraffin-embedded specimens, extracted with xylol at $37^{\circ} \mathrm{C}$ overnight, and digested with $2 \mathrm{mg} / \mathrm{ml}$ of hyaluronidase (Sigma Chemical Co.) at $37^{\circ} \mathrm{C}$ overnight. The specimens were then stained with siriun red (picrosirius staining). The sections were analyzed with an Ortholux 2 Pol-BK microscope (E. Leitz, Wetzlar, Germany) operated in monochromatic light $(\lambda=591$ $\mathrm{nm}$ filter for cartilage and $\lambda=656 \mathrm{~nm}$ filter for bone; Schott Mainz, Germany) using the de Sénarmont compensation technique.

\section{Staining of skeleton}

Fetal bones and cartilage were stained as described by Peters (1977). The skin and internal organs were removed, and the samples were fixed in $95 \%$ ethanol for 2 days followed by staining with $0.15 \%$ alcian blue in $70 \%$ ethanol and $20 \%$ acetic acid for 2 days. The samples were dehydrated in $100 \%$ ethanol for 2 days and immersed in $1 \% \mathrm{KOH}$ for 2 days. The samples were then stained in $0.0001 \%$ alizarin red $\mathrm{S}$ in $1 \% \mathrm{KOH}$ for 2 days before dehydration in graded solutions of glycerin and stored in $100 \%$ glycerin.

\section{Acknowledgments}

We are grateful to SYNTEX, Inc. (Palo Alto, CA) for the gift of Gancyclovir. The work was supported in part by National Institutes of Health grant PO39740, a grant from the Deutsche Forschungs-gemeinschaft (291/1-1), and a gift from the Lucille P. Markey Charitable Trust.

The publication costs of this article were defrayed in part by payment of page charges. This article must therefore be hereby marked "advertisement" in accordance with 18 USC section 1734 solely to indicate this fact.

\section{References}

Baldwin, C.T., A.M. Reginato, C. Smith, S.A. Jimenez, and D.J. Prockop. 1989. Structure of cDNA clones coding for human type II procollagen. The $\alpha 1$ (II) chain is more similar to the $\alpha 1$ (I) chain than two other $\alpha$ chains of fibrillar collagens. Biochem. I. 262: 521-528.

Capecchi, M.R. 1989. Altering the genome by homozygous recombination. Science 244: 1288-1292.

Caplin, A.I. 1988. Bone development. Cell and molecular biology of vertebrate hard tissues. Ciba Found. Symp. 136: 3-34.

Cheah, K.S.E., E.T. Lau, P.K.C. Au, and P.L.P. Tam. 1991. Expression of the mouse $\alpha 1$ (II) collagen gene is not restricted to cartilage during development. Development 111: 945-953.

Chu, M.-L. and D.J. Prockop. 1993. Collagen: Gene structure. In Connective tissue and its heritable disorders. Molecular, genetic, and medical aspects (ed. P.M. Royce and B. Steinmann), pp. 149-165. John Wiley \& Sons, New York.

Eyre, D.R., M.P. Upton, F.D. Shapiro, R.H. Wilkinson, and G.F. Vawter. 1986. Nonexpression of cartilage type II collagen in a case of Langer-Saldino achondrogenesis. Am. I. Hum. Genet. 39: 52-67.

Fassler, R., P.N. Schnegelsberg, J. Dausman, T. Shinya, Y. Muragaki, M.T. McCarthy, B.R. Olsen, and R. Jaenisch. 1994. Mice lacking $\alpha 1$ (IX) collagen develop noninflammatory degenerative joint disease. Proc. Natl. Acad. Sci. 91: 50705074.

Garofalo, S., E. Vuorio, M. Metsäranta, R. Rosati, D. Toman, J. Vaughan, G. Lozano, R. Mayne, J. Ellard, W. Horton, et al. 1991. Reduced amounts of cartilage collagen fibrils and growth plate anomalies in transgenic mice harboring a glycine-to-cysteine mutation in the mouse type II procollagen al-chain gene. Proc. Natl. Acad. Sci. 88: 9648-9652.

Gilbert, S.F. 1994. Early vertebrate development. Mesoderm and endoderm. In Developmental biology, 4th ed. (ed. S.F. Gilbert), pp. 323-338. Sinauer Associates, Sunderland, MA.

Hall, B.K. 1975. Evolutionary consequences of skeletal differentiation. Am. Zool. 15: 329-350.

. . 1992. The origin and evolution of vertebrate skeletal tissues. In Chemistry and Biology of Mineralized Tissues (ed. H. Slavkin and P. Price), pp 13-111. Excepta Medica, Elsevier Science Publishers, Amsterdam, The Netherlands.

Ham, A.W. and D.W. Carmack. 1979. Histology, pp. 377-462. J.B. Lippincott, Philadelphia, PA.

Hasty, P., M. Crist, M. Grompe, and A. Bradley. 1994. Efficiency of insertion versus replacement vector targeting varies at different chromosomal loci. Mol. Cell. Biol. 14: 8385-8390.

Helminen, H.J., K. Kiraly, A. Pelttari, M.I. Tammi, P. Vandenberg, R. Pereira, R. Dhulipala, J.S. Khillan, L. Ala-Kokko, E.L. Hume, B.P. Sokolov, and D.J. Prockop. 1993. An inbred line of transgenic mice expressing an internally deleted gene for type II procollagen (Col2A1). Young mice have a variable phenotype of a chondrodysplasia and older mice have osteoarthritic changes in joints. J. Clin. Invest. 92: 582-595.

Horton, W.A. 1992. Morphology of connective tissue. Cartilage. In Connective tissue and its heritable disorders. Molecular, genetic, and medical aspects (ed. P.N. Royce and B. Steinmann), pp. 73-84. Wiley-Liss, New York.

Jacenko, O. and T.S. Tuan. 1986. Calcium deficiency induces expression of cartilage-like phenotype in chick embyronic calvaria. Dev. Biol. 115: 215-232.

Johnson, R.L. and C. Tabin. 1995. The long and short of hedgehog signaling. Cell 81: 313-316.

Kravis, D. and W.B. Upholt. 1985. Quantitation of type II procollagen mRNA levels during chick limb cartilage differentiation. Dev. Biol. 108: 162-172. 
Li et al.

Li, S.-W., J. Khillan, and D.J. Prockop. 1995. The complete cDNA coding sequence for the mouse proa1(I) chain of type I collagen. Matrix Biol. 14: 593-595.

Li, Y., D.A. Lacerda, M.L. Warman, D.R. Beier, H. Yoshioka, Y. Ninomiya, J.T. Oxford, N.P. Morris, K. Andrikopoulos, F. Ramirez, B.B. Wardell, G.D. Lifferth, C. Teuscher, S.R. Woodward, B.A. Taylor, R.E. Seegmiller, and B.R. Olsen. 1995. A fibrillar collagen gene, Col11a1, is essential for skeletal morphogenesis. Cell 80: 423-430.

McIntosh, I., M.H. Abbott, and C.A. Francomano. 1995. Concentration of mutations causing Schmid metaphyseal chondrodysplasia in the C-terminal noncollagenous domain of type X collagen. Hum. Mutat. 5: 121-125.

Metsäranta, M., S. Garofalo, G. Decker, M. Rintala, B. de Crombrugghe, and E. Vuorio. 1992. Chondrodysplasia in transgenic mice harboring a 15-amino acid deletion in the triple helical domain of proal(II) collagen chain. I. Cell Biol. 118: 203-212.

Mortensen, R. 1993. Gene targeting by homologous recombination. In Current protocols in molecular biology (ed. F.M. Ausubel et al.|, Vol. 1, pp. 9.15.1-9.17.3. John Wiley / Greene, New York.

Nakata, A., K. Ono, J. Miyazaki, B.R. Olsen, Y. Muragaki, E. Adachi, K. Yamamura, and T. Kimura. 1993. Osteoarthritis associated with mild chondrodysplasia in transgenic mice expressing $\alpha 1(\mathrm{IX})$ collagen chains with a central deletion. Proc. Nat1. Acad. Sci. 90: 2870-2874.

Peters, P.W.J. 1977. Double staining of fetal skeletons for cartilage and bone. In Methods in prenatal toxicology led. D. Neuberg, H.-J. Merker, and T.E. Kwasigroch), pp. 153-154. Georg Thieme Verlag, Stuttgart, Germany.

Prockop, D.J. 1990. Mutations that alter the primary structure of type I collagen. The perils of a system for generating large structures by the principle of nucleated growth. $/$. Biol. Chem. 265: 15349-15352.

Prockop, D.J. and K.I. Kivirikko. 1995. Collagens. Molecular biology, diseases, and potentials for therapy. Ann. Rev. Biochem. 64: 403-434.

Prockop, D.J., H. Kuivaniemi, and G. Tromp. 1993. Heritable disorders of connective tissue. In Harrison's principles of internal medicine, 13th ed. (ed. J.D. Wilson, E. Braunwald, K.J. Isselbacher, R.G. Petersdorf, J.B. Martin, A.S. Fauci, and R.K. Root), pp. 2105-2107. McGraw-Hill Book Co., New York.

Pugh, R. 1968. Organogeny. In The mouse. Its reproduction and development, pp. 247-248. Burgers Publishing Co., Minneapolis, MN.

Reddi, A.H. 1994. Bone and cartilage differentiation. Curr. Opin. Genet. Dev. 4: 737-744.

Rimoin, D.L., and R.S. Lachman. 1990. Chondrodysplasias. In Principles and practices of medical genetics (ed. A.E. Emery, D.L. Rimoin, S.A. Sofaer, and I. Black), Vol. 2, pp. 895-832. Churchill Livingston, London, UK.

Ritvaniemi, P., J. Körkkö, J. Bonaventure, M. Vikkula, J. Hyland, P. Paasilta, I. Kaitila, H. Kääriäinen, B.P. Sokolov, M. Hakala, P. Mannismäki, E.M. Meerson, T. Klemola, C. Williams, L. Peltonen, K.I. Kivirikko, D.J. Prockop, and L. Ala-Kokko. 1995. Analysis of the COL2Al gene detects mutations in over 20 percent of patients with chondrodysplasias and up to 2 percent of patients with familial osteoarthritis. Arthritis Rheum. 38: 999-1004.

Ross, M.H., L.J. Romrell, and I.K. Gordon. 1989. Bone. In Histology. A text and atlas, 3rd ed., pp. 150-187. Williams and Wilkins, Baltimore, MD.

Schipani, E., K. Kruse, and H. Jüpper. 1995. A constitutively active mutant PTH-PTHrP receptor in Jansen-type metaph- yseal chondrodysplasia. Science 268: 98-100.

Shiang, R., L.M. Thompson, Y.Z. Zhu, D.M. Church, T.J. Fielder, M. Bocian, S.T. Winokur, and J.J. Wasmuth. 1994. Mutations in the transmembrane domain of FGFR3 cause the most common genetic form of dwarfism, achondroplasia. Cell 78: 335-342.

Thorogood, P. 1988. The development of specification of the vertebrate skull. Development (Suppl.) 103: 141-153.

Thorogood, P., J. Bee, and K. Von der mark. 1986. Transgenic expression of cartilage type II at epitheliomesenchymal interfaces during morphogenesis of the cartilagenous neurocranium. Dev. Biol. 116: 497-509.

Tremblay, P., and P. Gruss. 1994. Pax: Genes for mice and men. Pharm. Therapeut. 61: 205-206.

Vandenberg, P., J.S. Khillan, D.J. Prockop, H. Helminen, S. Kontusaari, and L. Ala-Kokko. 1991. Expression of a partially deleted gene of human type II procollagen (COL2Al) in transgenic mice produces a chondrodysplasia. Proc. Natl. Acad. Sci. 88: 7640-7644.

Vikkula, M., E.C.M. Mariman, V.C.H. Lui, N.I. Zhidkova, G.E. Tiller, M.B. Goldring, S.E.C. van Beersum, M.C. de Waal Malefijt, F.H.J. van den Hoogen, H.-H. Ropers, R. Mayne, K.S.E. Cheah, B.R. Olsen, M.L. Warman, and H.G. Brunner. 1995. Autosomal dominant and recessive osteochondrodysplasias associated with the COL11A2 locus. Cell 80: 431437.

von der Mark, K. and H. von der Mark. 1977. Immunological and biochemical studies of collagen type transition during in vitro chondrogenesis of chick limb mesodermal cell. J. Cell Biol. 73: 736-747.

Warman, M.L., M. Abbott, S.S. Apte, T. Hefferon, I. McIntosh, D.H. Cohn, J.T. Hecht, B.R. Olsen, and C.A. Francomano. 1993. A type X collagen mutation causes Schmid metaphyseal chondrodysplasia. Nature Genet. 5: 79-82.

Watanabe, H., K. Kimata, S. Line, D. Strong, L.Y. Gao, C.A. Kozak, and Y. Yamada. 1994. Mouse cartilage matrix deficiency ( $\mathrm{cmd}$ ) caused by a $7 \mathrm{bp}$ deletion in the aggrecan gene. Nature Genet. 7: 154-157.

Wong, M. and R.S. Tuan. 1995. Interactive cellular modulation of chondrogenic differentiation in vitro by subpopulations of chick embryonic calvarial cells. Dev. Biol. 167: 130-147.

Wood, A., D.E. Ashhurst, A. Corbett, and P. Thorogood. 1991. The transient expression of type II collagen at tissue interfaces during mammalian craniofacial development. Development 111: 955-968.

Wu, J.-J., D.R. Eyre, and H.S. Slayter. 1987. Type VI collagen of the intervertebral disc. Biochemical and electron-microscopic characterization of the native protein. Biochem. $J$. 248: 373-381.

Wu, J.-J., P.E. Woods, and D.R. Eyre. 1992. Identification of cross-linking sites in bovine cartilage type IX collagen reveals an antiparallel type II-type IX molecular relationship and type IX to type IX bonding. $J$. Biol. Chem. 267: 2300723014. 


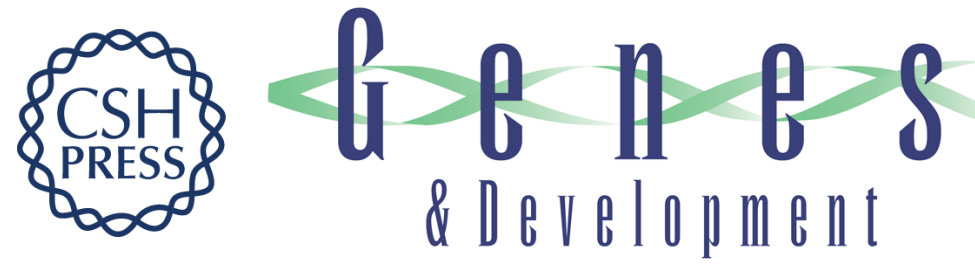

\section{Transgenic mice with targeted inactivation of the Col2 alpha 1 gene for collagen II develop a skeleton with membranous and periosteal bone but no endochondral bone.}

S W Li, D J Prockop, H Helminen, et al.

Genes Dev. 1995, 9:

Access the most recent version at doi:10.1101/gad.9.22.2821

References This article cites 36 articles, 16 of which can be accessed free at:

http://genesdev.cshlp.org/content/9/22/2821.full.html\#ref-list-1

License

Email Alerting

Service

Receive free email alerts when new articles cite this article - sign up in the box at the top right corner of the article or click here.

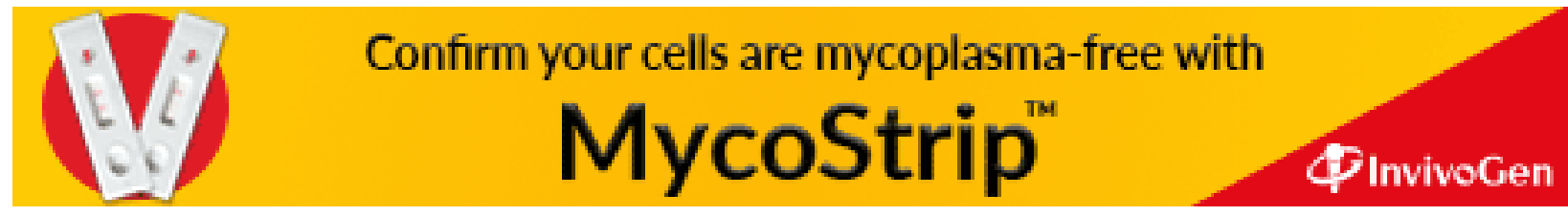

